\title{
Imbangan Media Penetasan terhadap Kemampuan Tetas dan Daya Hidup Jangkrik Gryllus mitratus
}

\section{Balance of Hatching Media on Hatchability and Life Capacity of Gryllus mitratus Cricket}

\author{
W. Sugma, Sutriyono, dan B. Brata \\ Jurusan Peternakan Fakultas Pertanian Universitas Bengkulu \\ Jl.WR.Supratman, Kandang Limun, Bengkulu, 38371A \\ Email:waliysugma@gmail.com
}

\begin{abstract}
This study aimed to evaluate the effect of hatching media balance on hatchability and survival of Gryllus mitratus cricket. Complete Random Design was used in this study, with 6 treatments and 5 replications. The treatments were $\mathrm{P} 0=100 \%$ river sand; $\mathrm{P} 1=100 \%$ beach sand; $\mathrm{P} 2=50 \%$ river sand $+50 \%$ beach sand; $\mathrm{P} 3=$ $75 \%$ river sand $+25 \%$ beach sand; $\mathrm{P} 4=25 \%$ river sand $+75 \%$ beach sand; $\mathrm{P} 5=$ without sand media. The data collected were the length of time of hatching, hatching, mortality, and the survival of crickets. Data were analyzed by analysis of variance (ANOVA) and continued with Duncan's Multiple Range Test (DMRT). The results of the study showed that the highest hatchability of cricket eggs was obtained on media without sand $(87.2 \%)$ and the best survival of crickets for 15 days was the use of mixed media $(75 \%$ river sand $+25 \%$ sand beach). ) with an average survival rate of $92.8 \%$.
\end{abstract}

Keywords: Gryllus mitratus, hatching media, hatchability, survival

\begin{abstract}
ABSTRAK
Penelitian bertujuan untuk mengevaluasi pengaruh imbangan media penetasan terhadap kemampuan tetas dan daya hidup jangkrik Gryllus mitratus. Rancangan Acak Lengkap digunakan dalam penelitian ini, dengan 6 perlakuan dan 5 ulangan. Perlakuan yang dicobakan adalah $\mathrm{P} 0=100 \%$ pasir sungai; $\mathrm{P} 1=100 \%$ pasir pantai; $\mathrm{P} 2=50 \%$ pasir sungai $+50 \%$ pasir pantai; $\mathrm{P} 3=75 \%$ pasir sungai $+25 \%$ pasir pantai $\mathrm{P} 4=25 \%$ pasir sungai + $75 \%$ pasir pantai; P5= tanpa media pasir. Data yang dikumpulkan adalah lama waktu menetas, daya tetas, mortalitas, dan daya tahan hidup anak jangkrik. Data dianalisis dengan analisis of varians (ANOVA) dan dilanjutkan dengan Duncan's Multiple Range Test (DMRT). Hasil dari penelitian menunjukkan bahwa kemampuan tetas telur jangkrik paling tinggi diperoleh pada media tanpa pasir $(87,2 \%)$ dan daya tahan hidup jangkrik yang paling baik selama 15 hari pembesaran jangkrik adalah pada penggunaan media campuran $(75 \%$ pasir sungai $+25 \%$ pasir pantai) dengan ratan daya tahan hidup sebesar $92,8 \%$.
\end{abstract}

Kata kunci: Gryllus mitratus, media penetasan, kemampuan tetas, daya tahan hidup

\section{PENDAHULUAN}

Keanekaragaman fauna di Indonesia merupakan salah satu komoditas dalam negeri yang perlu dikembangkan, termasuk diantaranya berasal dari kelas serangga yang terdiri dari lebih kurang 250.000 serangga atau $20 \%$ jumlah fauna serangga di dunia. Salah satu serangga yang dibudidayakan adalah jangkrik (Gryllus sp.) (Intania, 2006). Beberapa jenis jangkrik yang umumnya dibudidayakan yaitu: Jangkrik Cliring (Gryllus mitratus), Cendawang (Gryllus tetaceus) dan Kalung (Gryllus bimaculatus)
(Widyaningrum, 2001). Jangkrik Cliring (Gryllus mitratus) memiliki fase tumbuh yang lebih cepat dibandingkan jenis lainnya sehingga banyak dibudidayakan masyarakat.

Gryllus mitratus memiliki cirri khusus yaitu terdapat garis putih pada pinggir sayap punggung dan berperilaku lebih tenang. Siklus hidup semua jenis jangkrik relatif sama, umur jangkrik jantan lebih pendek dari pada betina. Jangkrik jantan dewasa umurnya dapat mencapai kurang lebih 78 hari, sedangkan untuk jangkrik betina dewasa umurnya bisa mencapai kurang lebih 105 hari. Gryllus mitratus menghasilkan telur 
\pm 1.200 butir sedangkan untuk jenis Gryllus testaceus telurnya \pm 500 butir dalam reproduksinya (Kumala, 1999). Jangkrik merupakan serangga yang telah populer di kalangan masyarakat dan telah dibudidayakan dengan tujuan untuk sumber pakan burung kicauan, pakan ikan, kosmetik dan bahan makanan karena mengandung protein cukup tinggi. Protein pada jangkrik terdiri dari protein omega-9, omega- 6 , dan omega-3, kemudian persentase protein yang terkandung dalam serangga ini per $100 \mathrm{~g}$ jauh lebih tinggi dibanding protein yang terdapat pada daging ayam, sapi dan udang (Budihardjo dan Setiawan, 2017).

Penyebaran jangkrik di Indonesia adalah merata, namun pasokan total dari pembudidaya hanya mampu menutupi sekitar $60 \%$ dari permintaan pasar dan terutama di kota-kota besar (Yusdira et al., 2016). Rendahnya pasokan jangkrik di pasaran dapat disebabkan oleh minimnya budidaya jangkrik pada masyarakat. Pembudidayaan jangkrik perlu ditingkatkan dalam upaya memenuhi kebutuhan pasar akan jangkrik.

Dalam budidaya jangkrik, ada beberapa aspek yang perlu di perhatikan, salah satunya adalah persiapan media penetasan. Media penetasan merupakan salah satu faktor penting dalam usaha budidaya jangkrik demi keberlangsungan regenerasi dalam sistem pemeliharaan (Yusdira et al., 2016). Persiapan media penetasan telur jangkrik perlu diperhatikan, karena dalam media inilah telur akan ditetaskan. Jika medianya kurang baik maka kemampuan tetas dan daya hidup jangkrik tidak maksimal. Para peternak biasanya menggunakan pasir sungai sebagai media tetas. Pada media ini kemampuan tetas telur jangkrik cukup bagus namun untuk daya hidup nimfa jangkrik belum begitu memuaskan bagi para peternak. Hal tersebut dikarenakan setelah telur-telur tersebut menetas masih ada nimfa-nimfa jangkrik yang mati sebelum memasuki fase imago (Alina et al., 2014).

Ada beberapa media lain yang bisa dijadikan sebagai media penetasan telur jangkrik yaitu media pasir pantai yang memiliki kadar garam yang lebih tinggi dari pada pasir sungai, penggunaan media koran bekas, kain basah dan kapas yang memiliki kemampuan untuk mempertahankan kelembaban. Sebagian peternak juga menggunakan abu dapur karena abu dapur memiliki unsur hara seperti yang terdapat pada tanah persawahan.

Bagian barat Provinsi Bengkulu merupakan dataran rendah yang berbatasan langsung dengan Samudera Indonesia dan membentuk garis pantai dengan panjang mencapai $525 \mathrm{~km}$ (PIRN-LIPI, 2016). Melihat potensi Provinsi Bengkulu dimana sebagian besar areal adalah laut, dan kondisi pesisir dengan limpahan pasir pantai, dengan demikian bukanlah hal yang sulit untuk mendapatkan pasir pantai sebagai bahan media tetas.

Pada penelitian ini dilakukan percobaan pengguaan pasir pantai dan pasir sungai sebagai media tetas telur jangkrik untuk mengetahui tingkat keberhasilan tetas dari telur jangkrik Gyrllus mitratus, dengan harapan peneliti bisa menemukan media yang bagus untuk meningkatkan kemampuan tetas dan daya tahan hidup jangkrik yang paling baik. Penelitian ini bertujuan mengevaluasi imbangan media penetasan terhadap kemampuan tetas dan daya hidup jangkrik Gryllus mitratus.

\section{METODE PENELITIAN}

Penelitian ini dilaksanakan pada bulan Maret hingga bulan April 2017 di Kelurahan Kandang Limun Kecamatan Muara Bangkahulu Kota Bengkulu.

Penelitian ini menggunakan 750 butir telur jangkrik, rumput Asystasia (nama umum: Ara Sungsang, Rumput Israel, Ganda Rusa), BR 1 (Broiler Strarter 1), pasir sungai dan pasir pantai yang mampu menahan air. Peralatan yang digunakan dalam penelitian ini adalah timbangan analitik merk ohaus, timbangan pegas, hygrometer, thermometer ruang, soil tester, soil thermometer, gelas ukur 10 dan $15 \mathrm{ml}$, kaca pembesar, spatula besi, hand sprayer, kuas, lakban, lem kayu, gunting, mistar, ember, tutup toples sosis diameter $10 \mathrm{~cm}$, insektisida kontak merk 
kapur Ajaib, kardus kertas bekas, egg tray (karpet telur) dan waring.

\section{Pembuatan media penetasan}

Mengayak pasir (pasir sungai maupun pasir pantai) menggunakan saringan kelapa, kemudian menaburkan secara merata pada tutup toples sosis berdiameter $10 \mathrm{~cm}$ dan tinggi $1,5 \mathrm{~cm}$ dipadatkan setebal $1 \mathrm{~cm}$. (pasir sungai dan pasir pantai yang telah dikomposisikan sesuai dengan perlakuan ditambahkan air menggunakan gelas ukur hingga didapatkan suhu media $29,8-30,6^{\circ} \mathrm{C}$, kelembaban $25-40 \%$ dan $\mathrm{pH}$ media 5,8-6,2). Selanjutnya menaburkan kembali pasir dengan keadaan gembur hingga batas atas tutup toples penuh dan ratakan menggunakan mistar aluminium. Gemburnya lapisan pasir bertujuan agar nimfa jangkrik lebih mudah untuk naik kepermukaan ketika proses penetasan.

\section{Persiapan kotak penetasan}

Kardus kertas bekas yang sudah dibersihkan dari debu dan kotoran, diolesi dengan menggunakan lem kayu diantara sambungan-sambungan kardus untuk menutupi celah lubang, kemudian merekatkan solasi disekeliling bagian atas kardus agar nimfa yang menetas tidak bisa keluar dari kardus.Peletakkan karpet telur yang telah dipotong (lebar dan panjang \pm 10 $\mathrm{cm}$ ) sebagai tempat persembunyian anakan yang baru menetas diletakkan pada hari ke 8 , sehari sebelum telur menetas.

\section{Penanganan telur}

Telur sampel diperoleh langsung dari peternak, media yang digunakan untuk tempat bertelur adalah pasir sungai, telur diambil pada hari ke-2. Telur yang sudah dipisahkan dari media tempat bertelur disimpan dalam kain katun basah dengan temperatur rendah untuk menjaga kelembaban sebelum dipindahkan ke media penetasan, kemudian dikirimkan ke lokasi penelitian pada hari tersebut (perjalanan \pm 5 jam dari Lubuklinggau- Bengkulu). Setelah telur tiba dilokasi penelitian, meletakkan telur sebanyak 25 butir pada tissue yang telah dibasahi menggunakan hand sprayer dan akan dilakukan penimbangan pada keesokan harinya (25 butir $\times 30$ sampel: 750 butir sampel telur).

\section{Pelaksanaan penetasan}

Meletakkan sebanyak 25 butir telur jangkrik pada masing-masing media penetasan, kemudian ditaburkan lagi pasir untuk menutupi permukaan telur agar temperatur telur tetap terjaga selama proses penetasan. Penyemprotan air pada media tetas menggunakan hand sprayer dilakukan setiap 1-2 hari sekali untuk menjaga agar kondisi media penetasan selalu dalam keadaan lembab. Perlunya penyemprotan telur 2 sampai 3 kali sehari pada media penetasan menggunakan air bersih agar terjaga kelembabannya (Kumala, 1999).

\section{Pemeliharaan nimfa (anakan jangkrik)}

Pemeliharaan dimulai saat telur pertama kali menetas yaitu pada hari ke sembilan hingga hari ke-13 yang ditandai dengan tidak adanya nimfa yang keluar dari media penetasan pada pagi hari (pukul 05:0008:00 pagi), kemudian pemeliharaan diteruskan sampai 10 hari berikutnya hingga hari ke-23. Pada penelitian ini nimfa dipelihara selama selama 10 hari. Menurut Saniah et al. (2014) dalam penelitiannya melaporkan bahwa jangkrik dipelihara selama 5 hari. Nimfa jangkrik yang baru menetas sampai usia 10 hari masih bisa hidup dalam tempat penetasan (Kumala, 1999).

Selama pemeliharaan nimfa diberi pakan rumput Asystasia (nama umum: Ara Sungsang, Rumput Israel, Ganda Rusa) dan BR 1 (Broiler Strarter 1) sebagai pakan tambahan. Pemberian pakan dilakukan pada pagi hari dan dilakukan pembaharuan pada hari berikutnya. Mekanisme pemberian adalah dengan memberikan 1 lembar daun asystasia pada kotak pemeliharaan kemudian pemberian BR1 (untuk melembutkan teksturnya maka ditambahkan sedikit air untuk melunakkan BR 1) dengan tujuan agar nimfa lebih mudah untuk memakan dan mencerna BR I yang diberikan.Pemberian pakan anakan jangkrik dilakukan sekali 
dalam sehari, dan waktu pemberian pakan dilakukan setiap pagi hari (Saniah et al., 2014).

Pemilihan tanaman asystasia dikarenakan tanaman ini memiliki jumlah kandungan air yang mendekati kandungan air pada tanaman kangkung yang sebelumnya diujikan pada pemeliharan anakan jangkrik dalam penelitiannya Saniah et al. (2014) menyatakan bahwa anakan jangkrik diberi makan sehelai daun kangkung segar karena jangkrik biasanya makan daun-daunan segar. Tanaman Asystasia juga biasanya dijadikan sebagai pakan kambing dan domba.

\section{Rancangan percobaan}

Penelitian telah dilakukan dengan menggunakan Rancangan Acak Lengkap (RAL) dengan 6 perlakuan dan 5 ulangan, dengan menggunakan telur jangkrik sebanyak 25 butir untuk setiap ulangan. Total telur yang dibutuhkan adalah $6 \times 5 \times 25=$ 750 butir. Penghitungan telur menggunakan spatula besi dan kaca pembesar. Perlakuan yang dicobakan dapat disarikan sebagai berikut :

P0 : Media pasir sungai $100 \%$

P1 : Media pasir pantai $100 \%$

P2 : Media campuran (50\% pasir sungai dan $50 \%$ pasir pantai)

P3 : Media campuran (75\% pasir sungai dan $25 \%$ pasir pantai)

P4 : Media campuran (25\% pasir sungai dan $75 \%$ pasir pantai)

P5 : Tanpa pasir (diletakkan pada cawan terbuka)

Model matematik dari rancangan yang digunakan adalah sebagai berikut :

$\mathbf{Y i j}=\boldsymbol{\mu}+\boldsymbol{\tau} \mathbf{i}+\mathbf{\varepsilon i j}$

Yij = Hasil pengamatan dari perlakuan ke-i dengan ulangan ke-j

$\mu \quad=$ Rata-rata pengamatan

$\tau \mathrm{i}=$ Pengaruh perlakuan ke-i

$\varepsilon i j=$ Pengaruh galat percobaan dari

perlakuan ke-i dan ulangan ke-j

\section{Lama waktu menetas}

Dihitung mulai dari telur diletakkan pada media tetas hingga telur tersebut menetas. Telur jangkrik apabila pada suhu dan kelembaban lingkungan yang sesuai akan menetas pada hari ke 13-20 hari setelah ditelurkan (Kumala, 1999).

\section{Persentase kemampuan tetas}

Dihitung pada hari ke-13 (telur mulai menetas pada hari ke-9 hingga hari ke-13), dimana semua telur dalam percobaan telah menetas semuanya yang ditandai dengan tidak adanya nimfa yang keluar dari media penetasan pada pagi hari (pukul 05:00-08:00) dihari ke-14. Penghitungan jumlah telur yang menetas dan total telur dilakukan pada setiap unit atau ulangan kemudian dibuat persentase yang hidup.

Kemampuan tetas $=\frac{\text { Jumlah telur menetas setiap unit }}{\text { Total telur setiap unit }}$

\section{Daya tahan hidup}

Dihitung pada hari ke-9 hingga hari ke24, hari ke-9 adalah dimana telur jangkrik mulai menetas. Saniah et al. (2014) menyatakan anakan jangkrik dipelihara selama 5 hari. Nimfa jangkrik yang baru menetas sampai usia 10 hari masih bisa hidup dalam tempat penetasan (Kumala, 1999). Penghitungan jumlah anak yang hidup dan total anakan dilakukan pada setiap unit atau ulangan kemudian dibuat persentase yang hidup.

$$
\text { Daya Hidup }=\frac{\text { Jumlah anakan hidup setiap unit }}{\text { Total anakan setiap unit }}
$$

\section{Suhu dan kelembaban ruangan penelitian}

Suhu dan kelembaban ruangan penelitian dihitung pada waktu pagi, siang dan sore hari selama 24 hari. Pengukuran suhu menggunakan thermometer ruangan dan pengukuran kelembaban menggunakan hygrometer. 


\section{Suhu kotak dan media penetasan}

Suhu kotak dan media penetasan dihitung selama 24 hari.Pengukuran suhu kotak menggunakan thermomoter ruang dan pada media penetasan menggunakan soil thermometer.

\section{Analisis Data}

Data yang diperoleh dianalisis dengan Analysis of varian (ANOVA), apabila terdapat perbedaan nyata $(\mathrm{P}<0,05)$ maka dilakukan uji lanjut dengan Duncan's Multiple Range Test (DMRT) untuk melihat perbedaan antar perlakuan (Nugroho, 2008).

\section{HASIL DAN PEMBAHASAN}

\section{Lama waktu menetas telur}

Pada Gambar 1 terlihat bahwa pada hari ke-9 telur mulai menetas hingga hari ke13. Hari ke-11 jumlah telur menetas paling tinggi yaitu P0 (100\% pasir sungai) : 54 butir, P2 (50\% pasir sungai $+50 \%$ pasir pantai) : 41 butir, P3 $(75 \%$ pasir sungai $+25 \%$ pasir pantai) : 56 butir, P4 (25\% pasir sungai + 75\% pasir pantai) : 41 butir, dan P5 : 43 butir. Perlakuan $100 \%$ pasir pantai menetas sebanyak 43 butir pada hari ke-10. Lama waktu menetas telur jangkrik dalam penelitian sama dengan pernyataan Kumala (1999) yang menyatakan bahwa telur jangkrik menetas pada kisaran hari ke-13 sampai hari ke-20.

\section{Persentase kemampuan tetas}

Hasil analisis ragam menunjukkan bahwa penggunaan media pasir pantai dan pasir sungai berpengaruh nyata $(\mathrm{P}<0,05)$ terhadap kemampuan tetas telur jangkrik. Kemampuan tetas P3 adalah paling rendah, yang berbeda nyata $(\mathrm{P}<0,05)$ jika dibandingkan dengan P0 (79,2\%), P1 $(83,2 \%)$, P2 $(78,4 \%)$, P4 $(76,8 \%)$, dan P5 $(87,2 \%)$. Hasil uji lanjut menunjukkan bahwa P3 merupakan media campuran $(75 \%$ pasir sungai $+25 \%$ pasir pantai) dengan kemampuan tetas sebesar 64\% (Tabel 1).

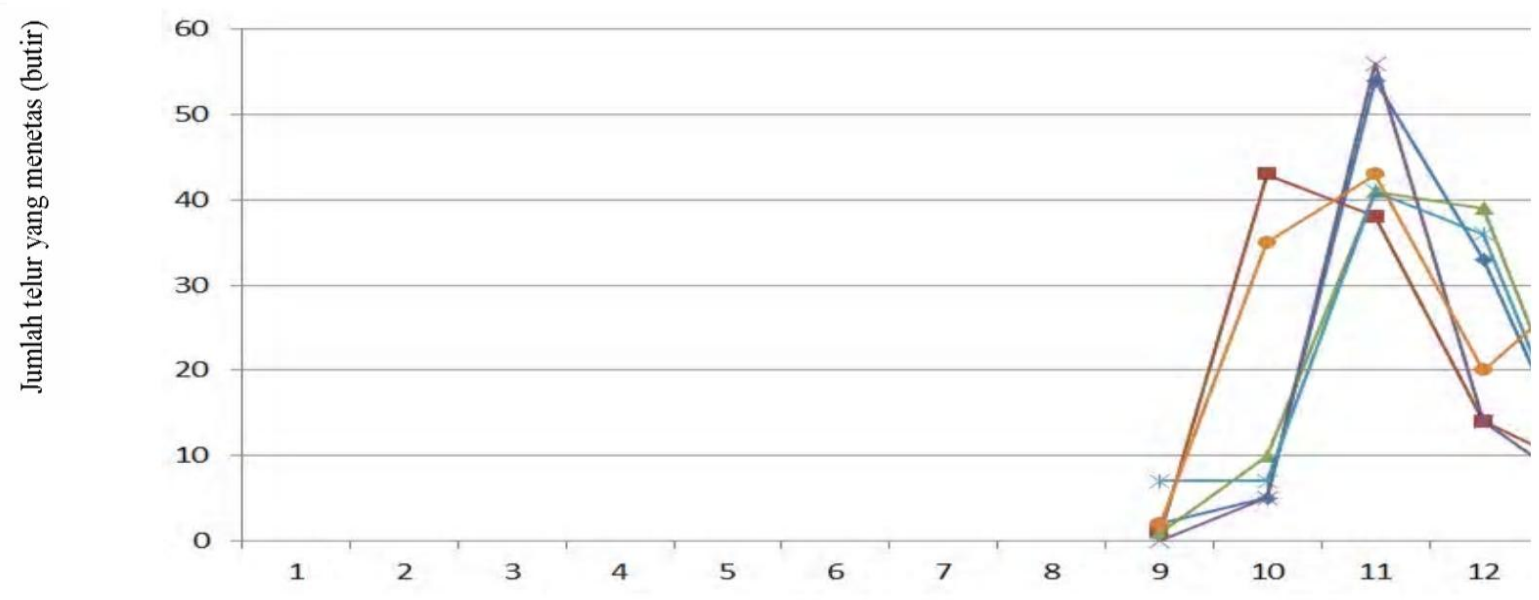

Hari ke

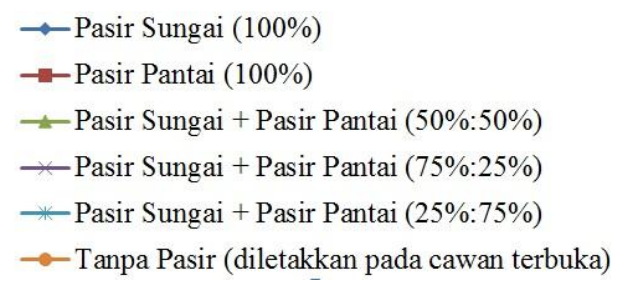

Gambar 1. Grafik lama waktu telur jangkrik Gryllus mitratus menetas 
Tabel 1. Kemampuan tetas telur jangkrik Gryllus mitratus

\begin{tabular}{lcccccc}
\hline \multirow{2}{*}{ Ulangan } & \multicolumn{7}{c}{ Perlakuan } \\
\cline { 2 - 7 } & P0 & P1 & P2 & P3 & P4 & P5 \\
\cline { 2 - 7 } & \multicolumn{7}{c}{$\ldots \ldots \ldots \ldots \ldots \% \ldots \ldots \ldots \ldots \ldots$} \\
\hline U1 & 88 & 96 & 76 & 56 & 92 & 84 \\
U2 & 68 & 72 & 76 & 60 & 68 & 88 \\
U3 & 84 & 92 & 72 & 72 & 68 & 88 \\
U4 & 88 & 76 & 100 & 72 & 80 & 88 \\
U5 & 68 & 80 & 68 & 60 & 76 & 88 \\
\hline Rataan & $79,2^{\mathrm{a}}$ & $83,2^{\mathrm{a}}$ & $78,4^{\mathrm{a}}$ & $64^{\mathrm{b}}$ & $76,8^{\mathrm{a}}$ & $87,2^{\mathrm{a}}$ \\
\hline SD & 10,35 & 10,35 & 12,52 & 7,05 & 10 & 1,80 \\
\hline
\end{tabular}

Keterangan: Superskrip yang berbeda pada baris yang sama menunjukkan perbedaan nyata $(\mathrm{P}<0,05)$.

P0 : Media pasir sungai $100 \%$

P1 : Media pasir pantai $100 \%$

$\mathrm{P} 2$ : Media campuran (50\% pasir sungai dan 50\% pasir pantai)

P3 : Media campuran (75\% pasir sungai dan 25\% pasir pantai)

P4 : Media campuran (25\% pasir sungai dan $75 \%$ pasir pantai)

P5 : Tanpa pasir (diletakkan pada cawan terbuka)

Walaupun kemampuan tetas pada P3 terendah diantara beberapa perlakuan yang diujikan, persentase ini lebih tinggi jika dibandingkan rataan persentase penetasan pada penelitian Widyaningrum et al. (2001) yang menyatakan bahwa daya tetas tertinggi dicapai oleh G. mitratus $(63,56 \%)$, kemudian diikuti G. bimaculatus $(60,23 \%)$, dan terendah adalah telur $G$. testaceus $(39,66 \%)$. Kelembaban relatif yang dibutuhkan untuk penetasan telur jangkrik berkisar antara $65 \%$ $85 \%$ dengan suhu udara $26^{\circ} \mathrm{C}$.Umumnya telur-telur jangkrik tidak menetas secara bersamaan, karena peletakkan telur dilakukan secara bertahap (Sridadi dan Rachmanto, 1999).

Rataan tertinggi yaitu $87,2 \%$ pada P5 diikuti oleh P1 dengan komposisi (100\% pasir sungai) yaitu $83,2 \%$. Persentase ini lebih tinggi dibanding dengan perolehan penelitian Alina et al. (2014) yaitu 66\%, dan pada penelitian Sinarto (2006) diperoleh hasil rataan yaitu $70 \%$. Penelitiaan keduanya menggunakan media yang sama yaitu pasir sungai.Menurut Widyaningrum (2001) telur yang berkualitas baik memiliki daya tetas yang tinggi, yaitu diatas $95 \%$, sedangkan yang berkualitas rendah daya tetasnya di bawah $50 \%$.

\section{Daya hidup}

Daya hidup nimfa jangkrik selama penelitian dapat dilihat pada Tabel 2. Hasil analisis ragam menunjukkan bahwa media penetasan mempengaruhi $(\mathrm{P}<0,05)$ daya hidup nimfa jangkrik selama 15 hari pemeliharaan dalam kotak penetasan, yaitu P5 $(23,2 \%)$ berbeda nyata dengan P1 $(86,4 \%)$, P2 $(90,4 \%)$, P3 $(92,8 \%)$, dan P4 $(84,8 \%)$. Daya hidup nimfa tertinggi diperoleh pada perlakuan media campuran (75\% pasir sungai dan $25 \%$ pasir pantai) dengan persentase hidup $92,8 \%$, angka ini jauh lebih tinggi jika dibandingkan dengan hasil penelitian Intania (2006) yang melaporkan bahwa persentase hidup anakan jangkrik sebesar 82\%. Perlakuan P5 memberikan daya hidup nimfa paling rendah $(23,2 \%)$ dan berbeda nyata $(\mathrm{P}<0.05)$ jika dibandingkan dengan perlakuan P0, P1, P2, P3, dan P4. 23,2\%. Kanibalisme dapat terjadi apabila dalam suatu populasi terdapat jangkrik yang kuat (besar) dan ada yang lemah (kecil). Jangkrik yang kuat dan besar biasanya memangsa yang lemah (Paimin,1999), sehingga dapat menurunkan jumlah nimfa yang hidup.

Tabel 2. Daya hidup nimfa jangkrik Gryllus mitratus

\begin{tabular}{ccccccc}
\hline \multirow{2}{*}{ Ulangan } & \multicolumn{7}{c}{ Perlakuan } \\
\cline { 2 - 7 } & P0 & P1 & P2 & P3 & P4 & P5 \\
\cline { 2 - 7 } & 76 & 100 & 92 & 96 & 96 & 16 \\
\hline U1 & 84 & 80 & 72 & 100 & 76 & 24 \\
U2 & 76 & 72 & 92 & 76 & 100 & 44 \\
U3 & 32 & 92 & 100 & 100 & 84 & 12 \\
U4 & 88 & 88 & 96 & 92 & 68 & 20 \\
U5 & $71,7^{\mathrm{b}}$ & $86,4^{\mathrm{b}}$ & $90,4^{\mathrm{b}}$ & $92,8^{\mathrm{b}}$ & $84,8^{\mathrm{b}}$ & $23,2^{\mathrm{a}}$ \\
\hline Rata-rata & 22,52 & 10,81 & 10,81 & 9,96 & 13,39 & 12,46 \\
\hline SD & 22,50
\end{tabular}

Keterangan: Superskrip yang berbeda pada baris yang sama menunjukkan perbedaan nyata $(\mathrm{P}<0,05)$.

P0 : Media pasir sungai $100 \%$

P1 : Media pasir pantai $100 \%$

P2 : Media campuran (50\% pasir sungai dan 50\% pasir pantai)

P3 : Media campuran (75\% pasir sungai dan 25\% pasir pantai)

P4 : Media campuran (25\% pasir sungai dan $75 \%$ pasir pantai)

P5 : Tanpa pasir (diletakkan pada cawan terbuka) 


\section{Suhu dan kelembaban ruangan penelitian}

Hasil pengamatan suhu dan kelembaban memperlihatkan bahwa suhu ruangan percobaan selama penelitian berada pada kisaran $27^{\circ} \mathrm{C}-34^{\circ} \mathrm{C}$ dengan kelembaban berkisar antara $82 \%-83 \%$. Jangkrik bisa ditemui dan hidup dengan baik pada daerah dengan lingkungan dikisaran suhu $20^{\circ} \mathrm{C}$ $32^{\circ} \mathrm{C}$ dan kelembaban 65\%-85\% (Sukarno, 1999). Suhu dan kelembaban ruangan penelitian masih dalam rentang normal seperti yang di sampaikan oleh Sukarno (1999).

Tabel 3. Suhu dan kelembaban ruangan penelitian

\begin{tabular}{ccc}
\hline & Suhu $\left({ }^{\circ} \mathrm{C}\right)$ & Kelembaban $(\%)$ \\
\hline Kisaran & $27-34$ & $82-83$ \\
Rataan & 30,31 & 82,71 \\
\hline
\end{tabular}

\section{Suhu kotak dan media penetasan}

Kondisi suhu kotak penetasan menunjukkan angka yang cenderung sama pada setiap unit perlakuan yaitu berkisar antara $27,5^{\circ} \mathrm{C}-31^{\circ} \mathrm{C}$ dengan total rataan untuk semua perlakuan adalah $29,36^{\circ} \mathrm{C}$. Suhu media penetasan memiliki kisaran antara $26,70^{\circ} \mathrm{C}-28,80^{\circ} \mathrm{C}$ dengan total rataan untuk semua perlakuan adalah $28,17^{\circ} \mathrm{C}$. Dari semua unit perlakuan P5 memiliki tingkat suhu lebih tinggi dibandingkan P0, P1, P2, P3, dan P4 baik suhu kotak maupun suhu media penetasan yaitu berkisar antara $28^{\circ} \mathrm{C}-31^{\circ} \mathrm{C}$ dan $27,30^{\circ} \mathrm{C}-28,80^{\circ} \mathrm{C}$.

Menurut Sridadi dan Rachmanto (1999) telur jangkrik membutuhkan suhu lingkungan sekitar $26^{\circ} \mathrm{C}$.Suhu kotak dan media penetasan pada penelitian sedikit lebih tinggi dari keterangan yang dijelaskan Rachmanto. Hal ini yang mempengaruhi adanya perbedaan jumlah dari kemampuan tetas telur jangkrik pada setiap unit percobaan.

Tabel 4. Suhu kotak dan media penetasan

\begin{tabular}{cccccccc}
\hline Ulangan & & P0 & P1 & P2 & P3 & P4 & P5 \\
\hline \multirow{2}{*}{ Kisaran } & Suhu & & $\ldots \ldots \ldots \ldots \ldots \ldots \ldots \ldots{ }^{\circ} \mathrm{C} \ldots \ldots \ldots \ldots \ldots \ldots \ldots \ldots \ldots$ & \\
& Kotak & $28-31$ & $27,5-31$ & $27,5-31$ & $27,5-31$ & $28-31$ & $28-31$ \\
& Media & $27,30-28,70$ & $27,30-28,70$ & $27,30-28,70$ & $26,70-28,70$ & $27,40-28,70$ & $27,30-$ \\
\multirow{2}{*}{ Rataan } & Kotak & 29,49 & 29,19 & 29,47 & 29,30 & 29,35 & 29,33 \\
& Media & 28,15 & 28,13 & 28,15 & 28,17 & 28,14 & 28,29 \\
\hline \multirow{2}{*}{ SD } & Kotak & 0,87 & 0,99 & 0,91 & 0,84 & 0,92 & 0,96 \\
& Media & 0,34 & 0,35 & 0,33 & 0,38 & 0,38 & 0,35
\end{tabular}

\section{KESIMPULAN}

Berdasarkan hasil penelitian dapat disimpulkan bahwa kemampuan tetas tertinggi $(87,2 \%)$ telur jangkrik terjadi pada penggunaan media tanpa pasir. Daya hidup terbaik selama 15 hari pemeliharaan adalah pada penggunaan media campuran $(75 \%$ pasir sungai $+25 \%$ pasir pantai) dengan rataan daya hidup sebesar $(92,8 \%)$.

\section{DAFTAR PUSTAKA}

Alina, D., L. Z. Armein dan K. Ria. 2014. Pengaruh media penetasan terhadap kemampuan tetas dan daya hidup jangkrik (Gryllus testaceus). Sekolah Tinggi Keguruan dan Ilmu Pendidikan (STKIP) PGRI Sumatera Barat.

Budihardjo, M dan B. Setiawan. 2017. Untung Berlipat dari Ternak Jangkrik. Penebar Swadaya. Jakarta.

Intania, A. 2006. Substitusi Tepung Kunyit (Curcuma domestica Val.) dalam Pakan Jangkrik Kalung (Gryllus bimaculatus) pada Periode Bertelur. 
[skripsi].Institut Pertanian Bogor. Sukarno, H. 1999. Budidaya Jangkrik. Bogor.

Cetakan I. Kanisius.Yogyakarta.

Kumala. L. 1999. Sukses Budidaya Jangkrik. Arkola. Surabaya.

Nugroho, S. 2008. Dasar-dasar Rancangan Percobaan.UNIB Press.Bengkulu.

Paimin, F. B. 1999. Mengatasi Permasalahan Jangkrik. Cetakan I. Penebar Swadaya. Jakarta.

PIRN-LIPI. 2016. Pemerintah Provinsi Bengkulu. http://pirn.lipi.go.id/provinsibengkulu. Bengkulu.07 April 2016.

Saniah, S. Purnawan dan S. Karina. 2014. Karakteristik dan kandungan mineral pasir pantai Lhok Mee, Beureunut dan Leungah, Kabupaten Aceh Besar. Jurnal Ilmu-ilmu Perairan Pesisir dan Perikanan. 3(3): 263-270.

Sinarto. E. 2016. Pengaruh media tetas terhadap daya tetas dan lama stadia nimfa jangkrik Gyrllus mitratus. Skripsi. Universitas Bengkulu. Bengkulu.

Sridadi dan Rachmanto, 1999. Teknik beternak jangkrik, cara mudah dan menguntungkan.

Widyaningrum, P. 2001. Pengaruh padat penebaran dan jenis pakan terhadap produktivitas tiga spesies jangkrik lokal yang dibudidayakan. [Disertasi]. Program Pascasarjana. Bogor (ID): Institut Pertanian Bogor. Bogor.

Widyaningrum, P., A. M. Fuah dan D. T. H. Sihombing. 2000. Produktivitas dua jenis jangkrik lokal Gryllus testaceus Walk dan Gryllus mitratus Burn (Orthoptera: Gryllidae) yang di budidaayakan. Berita Biologi. 5(2) : 171-174.

Widyaningrum, P., A.M. Fuah, D. T. H. Sihombing, dan A. Djuhara. 2001. Pengaruh sex rasio dan jenis pakan terhadap produksi dan daya tetas telur tiga jenis jangkrik lokal Gryllus bimaculatus De Geer, Gryllus mitratus Burn, dan Gryllus tetaceus Walk (Orthoptera : Gryllidae). Media Peternakan. 24(2) : 75-80.

Yusdira, A., S. Hidayatullah dan Tim Krotobond. 2016. Budidaya Jangkrik untuk Pakan Burung Kicauan, Semut Rangrang, Ikan Hias, dan Umpan Pancing. Agromedia. Jakarta. 